\title{
SVAR MODEL TO EXAMINE THE SHORT AND LONG TERM MONETARY POLICY IN INDONESIA
}

\section{TEGUH SUGIARTO}

\begin{abstract}
:
This research was conducted by the author to see the impact of monetary policy on the domestic macro-economic variables is important in Indonesia using a structural model of the short and long term, contained in a structural model of vectorAutoregressions (SVAR). The author uses the effects of macroeconomic policy is the key in this research, by applying the matrix model SVAR initiated by Bernanke \& Mihov (1998) short term and Blancard \& Quah (1989) long term. Research conducted using the 4 variables, consisting of two domestic variables, namely the interest rate of Bank Indonesia (SBI), the consumer price index (CPI) and two non-domestic variables, namely the interest rate the central bank United States(FFF), the rate of inflation in the United States (INF_USA). From the research that has been done can be inferred that the SVAR models used in this study can be used as a reference to the theoretical expectations in order to show that the rise in interest rates and the central bank of the United States could affect Indonesia's domestic variables.
\end{abstract}

\section{Keywords:}

SVAR, restricted short-term, restrictions long-term, IRF, FEVD, SBI, CPI, FFF, Inflation USA.

JEL Classification: C39, C01, B49

\section{Authors:}

TEGUH SUGIARTO, Budi luhur university, Indonesia, Email: teguh_cpconsulting@yahoo.com

\section{Citation:}

TEGUH SUGIARTO (2015). SVAR MODEL TO EXAMINE THE SHORT AND LONG TERM MONETARY POLICY IN INDONESIA. International Journal of Economic Sciences, Vol. IV(4), pp. 66-77., 10.20472/ES.2015.4.4.005 


\section{Introduction}

Some of the results of empirical research on the impact of monetary policy could be erratic. On the one hand Parado (2001) says, in the form of a large closed economy context, the effect of this policy is largely consistent with conventional theories. For example, in the United States (US), an increase in domestic interest rates, may tighten monetary policy, is if it is linked to the appreciation of the currency in host Kim and Roubini (2000). On the other hand Cushman \& Zha (1997) says that in the setting of a small open economy, the impact of monetary shocks do not seem consistent with existing economic theory. Another example as found by Sims (1992), the monetary contraction failed to reduce the level of house prices (a problem known as puzzle price). In addition, rising interest rates is often associated with the depreciation of the home currency (which is defined as a problem puzzle exchange rate).

This research will look at the impact of domestic monetary policy on key macroeconomic variables due to the influence of foreign variables Indonesia using SVAR approach. In addition, this study also will examine whether the response of short-term and long-term key macroeconomic variables Indonesian domestic monetary shocks are consistent with existing theory. In particular theory of monetary policy will reduce the absorption of the monetary aggregates of domestic variables Indonesia?

In building a model SVAR to model the Indonesian economy, there are two important things that need to be seen. First, Indonesia should be considered in the form of a small open economy, very sensitive to foreign shocks were exogenous. Therefore, to analyze the monetary policy in a small open economy setting, Cushman \& Zha (1997), Zha (1999), as well as Dungey \& Pagan (2000) suggest foreign exogeneity assumptions used blocks. In the context of the Indonesian economy models, this assumption see that there is an influence either directly or indirectly, the effect of dropping the Indonesian economy to foreign economies. Impose this restriction is not only interesting from an economic standpoint but also econometrically as to prevent any decisive as it existed on the model Zha, (1999).

\section{PREVIOUS RESEARCH}

Previous research identified the effects of a standard approach to monetary policy has been used Autoregressions vector (VAR). This approach does not have a strong theory in identifying monetary shocks initiated by recursive models of Kim and Roubini, (2000). Because of this, the results of studies using standard VAR may be biased as well as being contrary to the theory that there is monetary. Suppose the simultaneous reaction between monetary policy and exchange rate. In the standard VAR model, the exchange rate will mean react to all the other variables. Meanwhile, other variables (eg policy level) is placed before the exchange. This means that the interest rate used for that policy will only respond with a lag of the exchange rate. As a result, the relationship between interest rates and exchange rates, or interdependence simultaneously ruled out. But it does not apply, 
because the central bank may respond very rapidly exchange rate, this indicates that monetary policy has been identified as mentioned in Zaidi, (2011).

SVAR expansion model made by Sims \& Zha (1995a), Cushman \& Zha (1997), Kim \& Roubini (2000), which identifies the demand for money and the money supply in the context of a small open economy. Researchers impose the equation of money supply as the central bank reaction function. The difference between the two models of existing research Cushman \& Zha (1997) are more stringent in applying restrictions on foreign exogeneity block model of Kim \& Roubini (2000). The policy conducted by the Fed directly in research at Cushman \& Cushman and Zha justify it, while Kim \& Roubini (2000) did not. The existence of other differences in the study conducted by Cushman and Zha (1997) and Kim and Roubini assumed that domestic output and domestic price levels do not respond to extraneous variables, while Kim \& Roubini (2000) noted the importance of the impact of world price used variables.

The latter is a study conducted by Pirovano (2012), as amended by the model SVAR Neri (2004) and Li et al. (2010). In a study conducted by Pirovano (2012), he developed four models svar using seven variables to identify the impact of monetary policy on stock prices for the Czech Republic, Hungary, Poland and Slovenia. He found that the response of stock prices in countries that are more sensitive to changes in interest rates (Euro Area) foreigners than to shocks in one household. Moreover, changes in stock prices in these countries are also due to shocks in the exchange rate and monetary policy Eurozone. This implies that the domestic stock market is more sensitive to external shocks than domestic ones.

From the study of related theories and empirical research on the above, it can be concluded that a change in interest rates is a better indicator of innovation in monetary aggregates in identifying monetary policy shocks in Sims, (1992). It can also be concluded and it is expected that there will be appreciation of the exchange rate, the increase in imports in response to the tightening of monetary (interest rate increase). On the other hand, there will be a drop in stock price, the stock of money, export, the output and the price level in response to the policy of Facilities.

\section{RESEARCH METHODOLOGY}

\subsection{Time Research}

This research was conducted at the time of the month November 2014-March 2015.

\subsection{Model Approach In Research}

The approach in this research model based on the specifications of the structural model approach vector Autoregressions (SVAR) initiated by Bernanke \& Mihov (1998) to model the short term, as well as Blancard \& Quah (1989) for the long-term model, the authors did not use and discuss in detail SVAR models Zha (1997), Kim Cushman \& Roubini (2000), which many researchers make reference to the model SVAR. 


\subsection{Research Data}

This study uses monthly data from December 1984 to December 2012. Data derived international financial statistics (IFS) and the website of Bank Indonesia (BI), but the data is processed in advance by the author. This study divides the variables in the two blocks. The first block consists of domestic variables : a. Interest Rate of Bank Indonesia (SBI / BI_RATE), b. Indonesian Consumer Price Index (CPI), Then the second block consisting of non domestic variables: c. The interest rates on the American central bank (FFF), $d$. Inflation in the United States (INF_USA).

\section{RESEARCH RESULT}

The first part of this research begins with a discussion of the various diagnostic tests SVAR models short term and long term. Then, the second part is about the benchmark model. The focus of this second part is to discuss the impact of the domestic monetary policy on key macroeconomic variables inndonesia, to check whether the results of the research conducted is consistent with economic theory that is used, then the method of impulse response function (IRF) and variance decomposition error Fector (FEVD) in use. Furthermore, the last part is about the use of the model of Bernanke and Mihov and Blancard \& Quah which can be used as a handle for SVAR models in use.

\subsection{Diagnostic tests Model SVAR Short Run With 4 variables}

Short-term models in the idea Bernanke \& Mihov (1998). They examined the controversy about the effects of liquidity (LE) and LR neutrality M (LRN), simultaneously using SVAR. Here we see the results display SVAR models with models of short-term restrictions B \& M. 
Table 1 : SVAR model short run restriction with four variables

Structural VAR Estimates

Log likelihood

$-290.5183$

Estimated A matrix:

$\begin{array}{llll}1.000000 & 0.000000 & 0.000000 & 0.000000 \\ 1.766064 & 1.000000 & 0.000000 & 0.000000 \\ 0.005930 & -0.008594 & 1.000000 & 0.000000 \\ 0.005736 & 0.000885 & 0.075392 & 1.000000\end{array}$

Estimated B matrix:

\begin{tabular}{llll}
3.093596 & 0.000000 & 0.000000 & 0.000000 \\
0.000000 & 55.04453 & 0.000000 & 0.000000 \\
0.000000 & 0.000000 & 1.293683 & 0.000000 \\
0.000000 & 0.000000 & 0.000000 & 0.732869 \\
\hline \hline
\end{tabular}

Sources : Process by author

In general literature to assume that structural innovation has a diagonal covariance matrix that is by comparing the results of the literature, dividing each column B with the elements on the diagonal. For example:

$$
B=\left(\begin{array}{cc}
1 & b_{12} / b_{22} \\
b_{21} / b_{11} & 1
\end{array}\right)
$$

$B$ is a diagonal matrix, which results in the estimation matrix $A$ matrix multiplication as table 1: where in the model overidentified but passed the restrictions identified. Look at the results of model estimation matrix $A$, the result of multiplying domestic and non domestic variables, showed significant levels greater, so that we can be sure the models used svar short-term domestic and non domestic variables Indonesia in the economy there is interplay and there were affected.

\subsection{Diagnostic tests Model SVAR Long Run With 4 variables}

Long-term model identification results by: Blanchard \& Quah (1989) decomposition. B \& Q shows how macroeconomic variables and the recovery of pure shock (identify VARs) by assuming that long-term demand shocks could have an impact on the output of zero. As mentioned in section 3 (methodology), this study did not use diagnostic the information 
criterion FPE, AIC, SIC and HQIC to determine the optimal length, as a result, if there is value remaining two $(m=2)$ for all models. Restriction tests needed to confirm the identity over the validity of the identification in the model. Here the authors show for the results of the model svar Blancard \& Quah who took 4 of 8 models matrix.

Table 2 : SVAR model long run restriction with four variables

\section{Structural VAR Estimates}

Log likelihood $\quad-543.4630$

Estimated A matrix:

$\begin{array}{llll}1.000000 & 0.000000 & 0.000000 & 0.000000 \\ 0.000000 & 1.000000 & 0.000000 & 0.000000 \\ 0.000000 & 0.000000 & 1.000000 & 0.000000 \\ 0.000000 & 0.000000 & 0.000000 & 1.000000\end{array}$

Estimated B matrix:

$\begin{array}{llll}1.879493 & -2.143618 & 0.617889 & -1.860501 \\ -26.37196 & 28.79649 & 24.40726 & -25.90662 \\ 5162.112 & 4173.264 & 2860.738 & 2899.652 \\ -0.196626 & -0.542116 & 1.002078 & 0.820893\end{array}$

Sources : Process by author

Similarly, the short-term models svar literature, in the long-term model assumes that structural innovation has covar diagonal matrix by comparing the results of the literature, as well as dividing each column $B$ with the elements on the diagonal. If the short-term model is used as the handle is the result of multiplying that of the matrix $A$, but in the long run is the matrix $B$. We can see the result of the multiplication of domestic and non domestic variables Indonesia looks balanced, in the sense that there are domestic and non domestic variables in the long term affected and there were influences, but it is very obvious dependence in the long term, as a result of the estimation matrix $B$.

\subsection{Impulse Response Function (IRF)}

Model impulse response function is a practical way in analyzing visual data that represent the behavior of inflation and the unemployment rate in response to various shocks in an economy. Impulse response function is as a nuisance coefficients of the structural model. All functions of the impulse response in this study was calculated from the percent increase in disturbance and increased distractions can be understood to have a good effect for the economy. Here we see the impulse response of the data processing in this study. 
Figure 1 : IRF SVAR four variables

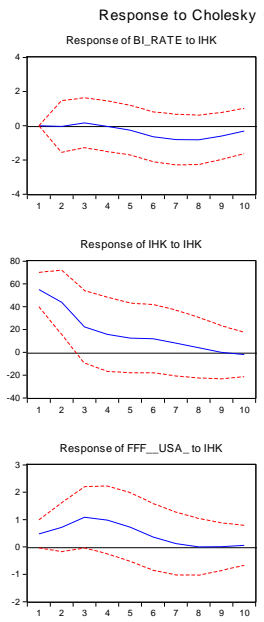

Response of INF_USA_tollt

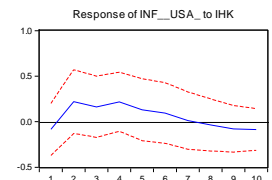

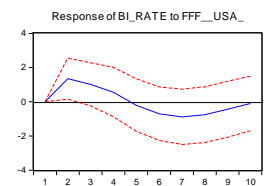
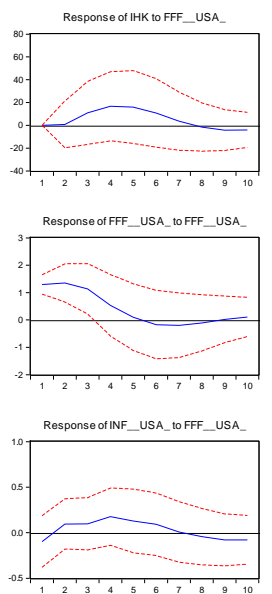

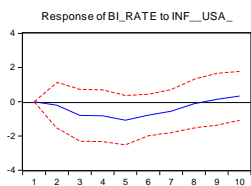

Response of IHK to INF_USA_
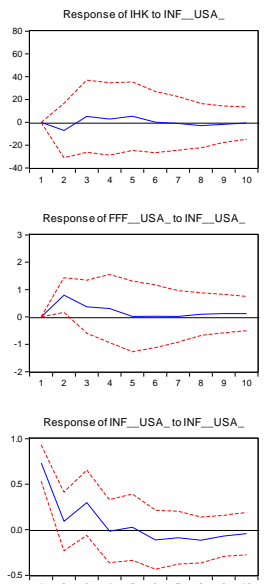

The IRF procedure is based the assumption that occurs contemporaneously independent between domestic variables with non domestic variables when shocks. To analyze at the beginning of shocks, with one variable and other variables, are also experiencing the same changes. If we see the impulse response graph shows the movement is getting closer to the point of balance or return to the previous equilibrium point. This indicates that the response of the variables due to the shocks the longer will disappear, so that the shocks did not leave a permanent effect on these variables.

From the image visible and shows the impact of the response received by $\mathrm{CPI}$ due to shocks and INF_USA FFF for 10 months is convergent, which is shown by the graph towards zero. A similar trend is also visible from shocks BI_Rate, FFF and INF_USA on the CPI.

\subsection{Fector Error Variance Decomposition (FEVD)}

Impulse response function analysis previously used to look at the impact of shocks from one variable to another variable, while the FEVD analysis is used to illustrate the relative importance of each variable in the system modeling using VAR base. 
Table 3 : Result FEVD with four variable in SVAR

\begin{tabular}{|c|c|c|c|c|c|}
\hline \multicolumn{6}{|c|}{$\begin{array}{l}\text { Variance Decomposition } \\
\text { of BI_RATE: }\end{array}$} \\
\hline Period & S.E. & BI_RATE & IHK & FFF_USA_ & INF_USA_ \\
\hline 1 & 3.093596 & 100.0000 & 0.000000 & 0.000000 & 0.000000 \\
\hline 2 & 3.490092 & 84.83671 & 0.013601 & 14.79213 & 0.357558 \\
\hline 3 & 3.871544 & 76.38536 & 0.204796 & 18.93715 & 4.472697 \\
\hline 4 & 3.999464 & 71.67379 & 0.199584 & 19.67919 & 8.447429 \\
\hline 5 & 4.173896 & 66.65257 & 0.560979 & 18.29892 & 14.48753 \\
\hline 6 & 4.420330 & 62.46706 & 2.613934 & 18.89764 & 16.02137 \\
\hline 7 & 4.666153 & 58.23817 & 5.379173 & 20.60323 & 15.77944 \\
\hline 8 & 4.831229 & 55.57396 & 7.938992 & 21.71115 & 14.77589 \\
\hline 9 & 4.897488 & 54.34628 & 9.248796 & 21.94390 & 14.46103 \\
\hline 10 & 4.919644 & 53.85914 & 9.553667 & 21.78944 & 14.79775 \\
\hline
\end{tabular}

Variance Decomposition of IHK:

\begin{tabular}{cccccc} 
Period & S.E. & BI_RATE & IHK & FFF_USA_ & INF_USA_ \\
\hline \hline 1 & 55.31501 & 0.975559 & 99.02444 & 0.000000 & 0.000000 \\
2 & 72.46886 & 4.795948 & 94.22565 & 0.007936 & 0.970471 \\
3 & 77.05315 & 4.953422 & 91.72473 & 2.000372 & 1.321472 \\
4 & 80.91879 & 5.636762 & 86.98521 & 6.051749 & 1.326279 \\
5 & 83.67239 & 5.422699 & 83.60798 & 9.311597 & 1.657724 \\
6 & 85.19793 & 5.253258 & 82.58635 & 10.56144 & 1.598951 \\
7 & 85.68385 & 5.247503 & 82.54082 & 10.61776 & 1.593917 \\
8 & 85.89978 & 5.343163 & 82.34713 & 10.60043 & 1.709279 \\
9 & 86.08458 & 5.465498 & 81.99394 & 10.79811 & 1.742454 \\
10 & 86.23186 & 5.515027 & 81.76452 & 10.97821 & 1.742247 \\
\hline \hline
\end{tabular}

Variance Decomposition of FFF_USA_: 


\begin{tabular}{cccccc} 
Period & S.E. & BI_RATE & IHK & FFF_USA_ & INF_USA_ \\
\hline \hline 1 & 1.378999 & 0.224213 & 11.76663 & 88.00916 & 0.000000 \\
2 & 2.208201 & 0.109959 & 15.15041 & 71.64254 & 13.09709 \\
3 & 2.735061 & 0.133274 & 25.54976 & 63.94964 & 10.36732 \\
4 & 2.972294 & 0.252253 & 32.56328 & 57.34253 & 9.841942 \\
5 & 3.065845 & 0.496306 & 36.25161 & 53.99848 & 9.253602 \\
6 & 3.095232 & 0.671653 & 36.94769 & 53.29575 & 9.084904 \\
7 & 3.104925 & 0.725001 & 36.87124 & 53.37226 & 9.031501 \\
8 & 3.108518 & 0.723436 & 36.78614 & 53.37732 & 9.113100 \\
9 & 3.111608 & 0.767471 & 36.71396 & 53.27538 & 9.243183 \\
10 & 3.117920 & 0.864380 & 36.60016 & 53.18035 & 9.355101 \\
\hline \hline
\end{tabular}

\begin{tabular}{lccccc}
$\begin{array}{l}\text { Variance Decomposition } \\
\text { of INF_USA_: }\end{array}$ & S.E. & BI_RATE & IHK & FFF_USA__ INF_USA_ \\
\hline Period & 0.744171 & 0.011521 & 1.285279 & 1.717772 & 96.98543 \\
\hline 1 & 0.820181 & 7.884609 & 8.270594 & 2.764545 & 81.08025 \\
2 & 0.917884 & 11.72505 & 9.762102 & 3.302302 & 75.21054 \\
3 & 0.985646 & 15.37166 & 13.34189 & 6.036142 & 65.25031 \\
5 & 1.012561 & 16.44932 & 14.32898 & 7.326340 & 61.89537 \\
6 & 1.029536 & 16.37897 & 14.70375 & 7.867463 & 61.04982 \\
7 & 1.033397 & 16.26039 & 14.60714 & 7.815375 & 61.31710 \\
8 & 1.042367 & 16.19976 & 14.47614 & 7.853986 & 61.47012 \\
9 & 1.052975 & 16.30599 & 14.75426 & 8.277790 & 60.66196 \\
\hline \hline & 1.062317 & 16.36628 & 15.17037 & 8.693533 & 59.76982 \\
\hline \hline
\end{tabular}

Cholesky Ordering:

BI_RATE IHK FFF__USA_ INF_USA

S.E : Standar error

Based on the table above shows that the source of the importance of variation BI_Rate is BI_Rate it self, while for the next period variation predicted value for BI_Rate variation 
predictive value of $84.36 \%$ was contributed by the CPI by $0.01 \%$, amounting to $14.79 \%$ of the FFF and by INF_USA by $0.35 \%$. So forth at month 10 shocks to the variable in question. Seen that shocks and influence of non domestic factors (FFF and INF_USA) is immense (Against BI_Rate) when compared with the domestic factor itself (CPI).

\section{CONCLUSION}

Research is conducted to look at the impact of macroeconomic variables from abroad Indonesia in analyzing monetary policy approach, which uses short term and long term structural vector Autoregressions at (SVAR). Diagnostic tests for identity-based restrictions, model BM and BQ can be used as a tool of analysis in the SVAR models other than the model developed by the Sim known as Zha \& KRBM and KRMM. From the research that has been done by the author can be inferred that the model used in this study supports the results of previous studies. Because of the limited number of observations to test this model is too complicated. But in this study provide an explanation of the restrictions that also serves as a policy analysis tool and the economic conditions in Indonesia.

However, the identification of schemes in all the models seem to be successful to identify the impact of monetary shocks on key macroeconomic variables for empirical puzzle solving the Indonesian economy. By looking at the impulse response function (IRF), the error variance decomposition fector (FEVD), Indonesian monetary policy seen contracting followed by appreciation of the variable factors of the domestic economy. So, when we see the results of the model SVAR short term and long term, it can be concluded that the domestic variables in Indonesia for monetary analysis influenced by larger factors from overseas. While domestic monetary variables that affect the Indonesia factor variable domestic monetary Indonesia itself was not great, as the output produced by the FEVD.

\section{References:}

Bernanke, B. (1986), Alternative explanations of the money-income correlation. Carnegie-Rochester Conference Series on Public Policy 25, 49-99.

Bernanke, Ben S. and Kuttner, Kenneth N. (2005), What explains the stock market's reaction to Federal Reserve policy? The Journal of Finance 60(3), 1221-1257. Retrieved from http://www.jstor.org/stable/3694925

Brischetto, A. and Voss, G. (1999). Structural vector autoregression model of monetary policy in Australia. Research Discussion Paper, Reserve Bank of Australia, 11.

Christiano, L., Eichenbaum M. and Evans, C. (1996). The effects of monetary policy shocks: evidence from the flow of funds. Review of Economics and Statistics 78(1), 16-34.

Cooley, Thomas F. and LeRoy, Stephen F. (1985). Atheoretical macroeconomics: a critique. Journal of Monetary Economics 16(2), 283 308. Retrieved from http://people.stern.nyu.edu/tcooley/papers/ath_mac_a_cri.pdf

Cushman, David O. and Zha, Tao. (1997). Identifying monetary policy in a small open economy under flexible exchange rates. Journal of Monetary Economics 39(3), 433-448. Retrieved from 
http://www.sciencedirect.com/science/article/pii/S0304393297000299

Dungey, M. and Pagan, A. (2000). A structural VAR of the Australian economy.

Economic Record, 76(235), 321-342.

Grilli, V. and Roubini, N. (1995). Liquidity and exchange rates: puzzling evidence from the G-7 countries. Yale University Working paper.

Ioannidis, Christos and Kontonikas, Alexandros. (2008). The impact of monetary policy on stock prices. Journal of Policy Modeling, 20(1), 33-53. Retrieved from http://www.sciencedirect.com/science/article/pii/S0161893807000932

Juanda, Bambang \& Junaidi," Ekonometrika Deret Waktu Teori \& Aplikasi". Penerbit PT Penerbit IPB Press. Bogor

Kim, Soyoung and Roubini, Nouriel. (2000). Exchange rate anomalies in the industrial countries: A solution with a structural VAR approach. Journal of Monetary Economics 45(3), 561-586. Retrieved from http://www.sciencedirect.com/science/article/pii/S0304393200000106

Kung, James J., Carverhill, Andre P. and McLeod, R.H. (2010). Indonesia's stock market: evolving role, growing efficiency. Bulletin of Indonesian Economic Penelitianes, 46 (3), 329-346 Retrieved from http://www.tandfonline.com/doi/pdf/10.1080/00074918.2010.522503

Leeper, E.M. and Gordon, D.B. (1991). In search of the liquidity effect. Journal of Monetary Economics 29, 341-369.

Mishkin, Frederic S. (1995). Symposium on the Monetary Transmission Mechanism. The Journal of Economic Perspectives, 9(4), 3-10. Retrieved from http://www.jstor.org/stable/2138387

Mishkin, Frederic S. (2004). The economics of money, banking and financial markets (7th ed.). the United States of America: Pearson Addison Wesley.

Mishkin, Frederic S. (2007). Monetary policy strategy. Cambridge, MA: Massachusetts Institute of Technology (MIT) Press.

Mishkin, Frederic S. and Serletis, Apostolos. (2011). The economics of money, banking and financial markets (4th Canadian ed.). Toronto: Pearson Addison Wesley.

Neri, Stefano. (2004). Monetary policy and stock prices: theory and evidence. Banca d'Italia working paper, July 2004. Retrieved from http://www.bancaditalia.it/pubblicazioni/econo/temidi/td04/td513_04/td513/ tema_513.pdf

Parrado, Eric. (2001). Effects of foreign and domestic monetary policy in a small open economy: the case of Chile. Central Bank of Chile working papers. Retrieved from http://EconPapers.repec.org/RePEc:chb:bcchwp:108

Pirovano, Mara. (2012). Monetary policy and stock prices in small open economies: Empirical evidence for the new EU member states. Economic Systems 36(3), 372-390. Retrieved from http://www.sciencedirect.com/science/article/pii/S0939362512000532

Prastowo, Nugroho Joko. (2007). The impacts of BI rate on financial markets: to measure the significance response of financial market instruments to monetary policy. Trans. Bank Indonesia working paper (21). Retrieved from http://www.bi.go.id/NR/rdonlyres/E530189B-025B-4EEE-985D- 


\section{C048446/20773/WP200721.pdf}

Reichenstein, W. (1987) The impact of money on short term interest rates. Economic Inquiry 25, 67-82

Rosadi, Dedi, (2012)," Ekonometrika Analisis Runtun Waktu Terapan Dengan Eviews Aplikasi Untuk Bidang Bisnis dan Keuangan". Penerbit ANDI Yogyakarta.

Saugi, Yahdin A. (2013). Focus emerging markets in Indonesia. Retrieved from http://www.bnpparibasip.com/publications/documents/other/IP/documentlist/newsletters/in-touch/20130711_in-touch242_eng_eng.pdf

Sellin, Peter. (2001). Monetary policy and the stock market: theory and empirical evidence. Journal of Economic Surveys 15(4), 491-541. Retrieved from http://onlinelibrary.wiley.com/doi/10.1111/1467$6419.00147 / \mathrm{pdf}$

Sims, C.A. (1986). Are forecasting models usable for policy analysis. Federal Reserve Bank of Minneapolis Quarterly Review, 10(1), 2-15.

Sims, C.A. (1992). Interpreting the macroeconomic time series facts: the effects of monetary policy. European Economic Review 36 (5), 975-1000.

Sims, C. A. and Zha, T. (1995a). Does monetary policy generate recessions? Yale University Working Paper.

Sims, C. A. and Zha, T. (1995b). Error bands for impulse responses. Federal Reserve Bank of Atlanta Working Paper, 95-96.

Sterman, David. (2013). The most undervalued emerging market In the world. Retrieved from http://www.streetauthority.com/international-investing/most-undervalued-emerging-market-world475780

Thorbecke, Willem. (1997). On stock market returns and monetary policy. The Journal of Finance 52(2), 635654. Retrieved from http://www.jstor.org/stable/2329493

Rezessy, András. (2006). Estimating the immediate impact of monetary policy shocks on the exchange rate and other asset prices in Hungary. In Magyar Nemzeti Bank (Eds.), Monetary Transmission in Hungary. Retrieved from http://www.mnb.hu/Root/Dokumentumtar/ENMNB/Monetaris_politika/mn ben_Monetary_Transmission_in_Hungary/monetary_transmission_in_hung ary.pdf

Vargas, Armando Sánchez. (2009). A review of Stata SVAR modeling capabilities. Mexican Stata Users' Group Meetings, Stata Users Group, 2009. Retrieved from http://repec.org/msug2009/mex09sug_asv.ppt 03.

Zaidi, Mohd Azlan Shah. (2011). "Structural vector autoregressive analysis of monetary policy in Malaysia". $\mathrm{PhD}$ thesis. Economics, Australian School of Business University of New South Wales, Economics, 2011. Retrieved from http://unsworks.unsw.edu.au/fapi/datastream/unsworks:9142/SOURCE02 